\title{
ANTIOXIDANT ACTIVITY OF TARENNA POLYCARPA (MIQ.) KOORD. LEAF
}

\author{
RIKA PUSPITA SARI ${ }^{1 *}$, MARLINE NAINGGOLAN ${ }^{1}$, ROSIDAH $^{2}$
}

${ }^{1}$ Department of Pharmaceutical Biology, Faculty of Pharmacy, University of Sumatera Utara, Medan, Indonesia. ${ }^{2}$ Department Pharmacology, Faculty of Pharmacy, University of Sumatera Utara, Medan, Indonesia. Email: rika.puspitasari.rika@gmail.com

Received: 10 August 2017, Revised and Accepted: 22 December 2017

ABSTRACT

Objective: The objective of this study is to evaluate the antioxidant activity of Tarenna polycarpa (Miq.) koord. Ex Valenton. Leaf extract and fractions.

Methods: Antioxidant activity was examined by DPPH method.

Results: Ethanol extract, n-hexane fraction, and ethyl acetate fraction with DPPH assay measured as half maximal inhibitory concentration were $55.21,109.73$, and $42.04 \mu \mathrm{g} / \mathrm{mL}$, respectively.

Conclusions: The results reveal that T. polycarpa extract and fractions have strong antioxidant potential. Our further study is to isolate compounds responsible for antioxidant components.

Keywords: Antioxidant, Tarenna polycarpa, Leaf, Extract, Fractions.

(C) 2018 The Authors. Published by Innovare Academic Sciences Pvt Ltd. This is an open access article under the CC BY license (http://creativecommons. org/licenses/by/4. 0/) DOI: http://dx.doi.org/10.22159/ajpcr.2018.v11i4.21929

\section{INTRODUCTION}

Oxidation is one of important processes in living organisms. Free radicals are increasing from metabolism or environmental sources interact continuously with biological system $[1,2]$. Reactive species are molecules or atoms which have an electronic unstability and most reactive [3]. The uncontrolled production of oxygen free radicals and the unbalanced mechanism of antioxidant protection result in the onset of many diseases such as cancer, diabetes, Alzheimer's, heart diseases, and aging [2,4-6].

Tarenna polycarpa (Miq.) Koord. Ex Valenton. (morbesi-besi) has been used as immunostimulator in Tapanuli and Sibolga [7]. Tarenna asiatica has the same genus with T. polycarpa which contained of flavonoid as antioxidant and antimicrobial $[8,9]$. The aim of this study was to determine antioxidant activities of T. polycarpa (Miq.) Koord. Ex Valenton leaves.

\section{MATERIALS AND METHODS}

Plant and chemicals material

Fresh leaves of T. polycarpa (Miq.) were collected from Sibolga Sambas, Sibolga City, Sumatera Utara province, Indonesia. T. polycarpa (Miq.) was identified in Research Center for Biology, Indonesian Institute of Science, Bogor, and the voucher specimen was deposited in herbarium. Chemicals used were distilled water, 1,1-diphenyl-2-picrylhydrazyl (DPPH) (Sigma), methanol (Merck).

\section{Preparation of ethanol extract (EE)}

The air-dried and powdered leaves of T. polycarpa (Miq.) (1 kg) were extracted by cold maceration with ethanol $80 \%$ (7.5 L) for 5 days with soaked, filtrate was collected, and residue was washed with $2.5 \mathrm{~L}$ of ethanol $80 \%$, and filtrate was collected in the same bottle and then evaporated under reduced pressure to give a viscous extract and then freeze-dried to dry [10-13].

Preparation of n-hexane (NHF) and ethyl acetate fraction (EAF) The EE was added with $100 \mathrm{~mL}$ aquadest to yield liquid form of ethanolic extract. The extract was fractioned with NHF and ethyl acetate, respectively, and fractions were evaporated under reduced pressure to give a dry fraction [14].

Free radical scavenging activity test

The free radical scavenging activity was measured by 1,1-diphenyl-2-picrylhydrazyl (DPPH) method of Blois (1958). $0.2 \mathrm{mM}$ solution of DPPH in methanol was prepared, and $100 \mu \mathrm{l}$ of this solution (EE, NHF, and EAF) was added to various concentrations; 25, 50, 75, and $100 \mu \mathrm{g} / \mathrm{ml}$. After $60 \mathrm{~min}$ absorbance was measured at $516 \mathrm{~nm}$. All the tests were performed in triplicate and percentage of inhibition was calculated by comparing the absorbance values of the control and test samples $[1,2,4,15]$.

Percentage of inhibition $=\frac{\text { Abs control }- \text { Abs test }}{\text { Abs control }} \times 100 \%$

Statistical analysis

Data were expressed as a mean \pm standard deviation. Analysis of variance (ANOVA) with the Tukey post hoc test was used for multiple comparison. All statistics were analyzed using the SPSS 20 software.

\section{RESULTS AND DISCUSSION}

\section{Antiradical activity}

Antiradical power of the plant samples was measured in terms of hydrogen-donating ability using DPPH which is a stable, nitrogencentered free radical and produces deep purple color in methanol solution. Antioxidants either transfer an electron or a hydrogen atom to DPPH, thus neutralizing its free radical character [16]. DPPH test, which is based on the ability of DPPH, a stable free radical, to decolorize in the presence of antioxidants, is a direct and reliable method for determining radical scavenging action [17]. The DPPH assay has been largely used as a quick, reliable, and reproducible parameter to search the in vitro general antioxidant activity of pure compounds as well as plant extracts [18]. The reducing capacity of compounds could serve as an indicator of potential antioxidant property [19]. It is very 
important to point out that a low half maximal inhibitory concentration $\left(\mathrm{IC}_{50}\right)$ value reflects a high antioxidant activity of the fraction since the concentration necessary to inhibit the radical oxidation in $50 \%$ is low. $\mathrm{IC}_{50}$ for EE, NHF, and EAF in DPPH assay was 55.21, 109.73, and 42.04 $\mu \mathrm{g} / \mathrm{mL}$, respectively.

\section{AUTHORS CONTRIBUTION}

RPS : Doing all the research. MN: Editing manuscript. Ros: Preparing manuscript and analysis data.

\section{CONFLICT OF INTEREST}

There is no conflict of interest to be reported.

\section{REFERENCES}

1. Satria D, Silalahi J, Haro G, Ilyas S, Hsb PA. Antioxidant and antiproliferative activities of an ethylacetate fraction of picria fel-terrae lour. Herbs Asian Pac J Cancer Prev 2017;18:399-403.

2. Rosidah, Yam MF, Sadikun A, Asmawi MZ. Antioxidant potential of Gyunura procumbens. Pharm Biol 2008;46:616-25

3. Hasibuan PA, Sitorus P, Satria D. Anticancer activity of $\beta$-sitosterol from Plectranthus amboinicus (Lour. Spreng.) leaves: In vitro and in silico studies. Asian J Pharm Clin Res 2017;10:306-8.

4. Jamuna S, Pulsamy S, Karthika K. Screening of in vitro antioxidant activity of methanolic leaf and root extracts of Hypochaeris radicata $\mathrm{L}$. (Asteraceae). J Appl Pharm Sci 2012;2:149-54

5. Nagmoti DM, Khatri DK, Juvekar PR, Juvekar AR. Antioxidant activity free radical-scavenging potential of Pithecellobium dulce Benth seed extracts. Free Radic Antioxid 2012;2:37-43

6. Yang YC, Lu FH, Wu JS, Wu CH, Chang CJ. The protective effect of habitual tea consumption on hypertension. Arch Intern Med 2004; $164: 1534-40$

7. Anonim. (2016). Morbesi-bosi. (289614). [Last retrieved on 2016 May 19].

8. Kuntzeex SS, Anjanadevi N, Abirami P, dan Sharmila S. Antibacterial activity of leaf extract of Tarenna asiatica (L.). Indian J Microbiol Sci 2014:3:48-51.

9. Ramabharathi V. Phytochemical Investigation of the Gum Resin of Tarenna asiatica. Vol. 11. Dissertation. Tirupati (WU): Women University; 2011. p. 3-9.

10. Satria D, Furqan M, Hadisahputra S, Rosidah. combinational effects of ethylacetate extract of Picria fel-terrae Lour. and doxorubicin on T47D breast cancer cells. Int J Pharm Pharm Sci 2015;7:73-6.

11. Sitorus P, Satria D. Antibacterial activity of ethanol extract and volatile oil of laja gowah rhizome (Alpinia malaccensis Burm. F Roscoe.) against Staphylococcus aureus and Escherichia coli. Asian J Pharm Clin Res 2016;8:466-8.

12. Anggraeni R, Hadisahputra S, Silalahi J, Satria D. Combinational effects of ethylacetate extract of Zanthoxylum acanthopodium DC. With doxorubicin on T47D breast cancer cells. Int J PharmTech Res 2014;6:2032-5

13. Hasibuan PA, Jessy C, Denny S. Combination effect of ethylacetate extracts of Plectranthus ambonicius (Lour.) Spreng. With doxorubicin againts T47D breast cancer cells. Int J Pharm Pharm Sci 2015;7:155-9.

14. Satria D, Pandapotan M, Illyas S. Cytotoxcicity effect of sea horse (Hippocampus trimaculatus Leach.) extract and fractions on MCF-7 cell line. Int J Pharmtech Res 2014;6:212-6.

15. Dalimunthe A, Achmad S, Satria D. Phenolic, flavonoid content and antioxidant activities of ethylacetate extract of Litsea cubeba (Lour.) Pers. Barks. Der Pharma Chem 2016;8:466-8.

16. Pan Y, Wang $\mathrm{K}$, Huang S, Wang $\mathrm{H}, \mathrm{Mu} \mathrm{X}, \mathrm{He} \mathrm{C}$, et al. Antioxidant activity of microwave-assisted extract of longan (Dimocarpus longum Lour.) peel. Food Chem 2008;106:1264-70.

17. Hasan SM, Hossain MM, Akter R, Jamila M, Mazumder ME, Rahman S. DPPH free radical scavenging activity of some Bangladeshi medicinal plants. J Med Plants Res 2009;3:875-9.

18. Koleva II, van Beek TA, Linssen JP, de Groot A, Evstatieva LN. Screening of plant extracts for antioxidant activity: A comparative study on three testing methods. Phytochem Anal 2002;13:8-17.

19. Meir S, Kanner J, Akiri B, Hada SP. Determination and involvement of aqueous reducing compounds in oxidative defense system of various senescing leaf. J Agric Food Chem 1995;43:1813-9. 